\title{
How do zooplankton respond to coastal wetland restoration? the case of newly created salt marsh lagoons in La Pletera (NE Catalonia)
} \author{
Lucas Barrero and Xavier D. Quintana \\ GRECO, Institute of Aquatic Ecology, University of Girona, 17003 Girona, Spain. \\ * Corresponding author: jscg88@gmail.com
}

Santiago Cabrera*, Jordi Compte, Stéphanie Gascón, Dani Boix, David Cunillera-Montcusí,

Received: $16 / 02 / 18 \quad$ Accepted: $14 / 01 / 19$

\begin{abstract}
How do zooplankton respond to coastal wetland restoration? The case of newly created salt marsh lagoons in La Pletera (NE Catalonia)

We analysed the changes in the zooplankton composition in several new and old lagoons in La Pletera, a confined Mediterranean coastal salt marsh located in the Baix Ter wetlands (NE Iberian Peninsula) that was subjected to a restoration project (Life Pletera). We sampled the zooplankton from three new lagoons immediately after their creation (1 and 2 months after), and we compared the zooplankton with those of three existing lagoons, two natural lagoons and one lagoon created fourteen years ago in a previous restoration project. The sampling included seven months before the first hydrological connection to the surface waters, when flooding during a sea storm connected the new lagoons with the existing lagoons for the first time, and seven months after. The results showed that the nutrient and organic matter concentrations were lower in the new lagoons than in the old lagoons, suggesting accumulation processes in these ecosystems, which were probably related to the long periods of confinement that typically follow flooding events in this type of lagoons. However, we did not find significant differences in the zooplankton community between the old and new lagoons. The seasonal variation in the zooplankton communities was strongly affected by the seasonal hydrological flooding - confinement pattern, which did not differ between the old and new lagoons. Calanoid copepods, mainly Eurytemora velox, dominated during winter, while the rotifer Brachionus plicatilis dominated in summer, coinciding with the highest degree of confinement. The environmental variables and the hydric connection explained $31 \%$ of the zooplankton variability. The high connectivity of the system once it flooded aided dispersal, the hatching of the egg banks existing in the restored lagoons and the fast response of the zooplankton species to changes in the environmental conditions (although with some degree of delay) might explain the lack of significant differences between the zooplankton composition in the old and new lagoons.
\end{abstract}

Key words: zooplankton, coastal lagoons, flooding confinement, restoration, high dispersal, egg banks

\section{RESUMEN}

¿Cómo responde el zooplancton a la restauración de un humedal costero? El caso de las lagunas recientemente creadas en la marisma de La Pletera (NE Cataluña)

Se analizaron los cambios en la composición del zooplancton en algunas lagunas de nueva creación y ya existentes de La Pletera, una marisma confinada en la costa del Mediterráneo, localizada en los humedales del Baix Ter (NE Península Ibérica) y sujeta a un proyecto de restauración Life (Life Pletera). Se muestreó el zooplancton de tres nuevas lagunas inmediatamente después de su creación (1 o 2 meses después) y se comparó con el de tres ya existentes; dos lagunas naturales y una creada catorce años antes en un proyecto de restauración previo. Los muestreos incluyeron siete meses antes de la primera conexión hídrica superficial, cuando el proceso de inundación durante los temporales de mar conectó por primera vez las nuevas lagunas con las ya existentes, y los siete meses posteriores. Los resultados mostraron que la concentración de nutrientes y materia orgánica fue más baja en las nuevas lagunas que en las viejas, sugiriendo un proceso de acumulación en estos ecosistemas, probablemente relacionada con los largos periodos de confinamiento que normalmente siguen a los eventos de inundación en este tipo de lagunas. Por otro lado, no se encontró diferencias significativas en la comunidad zooplanctónica 
entre lagunas viejas y nuevas. El patrón temporal del zooplancton estuvo fuertemente afectado por el patrón temporal hidrológico de inundación-confinamiento, el cual no difiere entre lagunas viejas y nuevas. Los copépodos calanoides, principalmente Eurytemora velox, dominaron durante el invierno, mientras que el rotífero Brachionus plicatilis dominó en verano coincidiendo con el mayor grado de confinamiento. Las variables ambientales y la conexión hídrica explican un $31 \%$ de la variabilidad del zooplancton. La elevada facilidad de dispersión entre lagunas ubicadas muy cerca y fácilmente conectadas durante los eventos de inundación, la eclosión del banco de huevos existente en las lagunas restauradas y la respuesta rápida de las especies zooplanctónicas a los cambios en las condiciones ambientales (aunque con algún grado de retraso), podría explicar la falta de diferencias significativas entre la composición del zooplancton en las lagunas viejas y nuevas.

Palabras clave: zooplancton, lagunas costeras, inundación-confinamiento, restauración, dispersión alta, banco de huevos

\section{INTRODUCTION}

Coastal lagoons are ecosystems that suffer different kinds of anthropogenic threats (e.g., Miracle et al., 1984; Carrillo et al., 1987; Comín et al., 1987; Vicente \& Miracle, 1992; Pérez-Ruzafa \& Marcos, 2005; Romo et al., 2005). They occupy approximately $13 \%$ of the coastal areas in the world (Kjerfve, 1994) and are surrounded by strongly populated areas since approximately 40 $\%$ of human populations live within 100 kilometres of a coast (Small \& Nicholls, 2003; Neumann et al., 2015). Coastal lagoons have an important ecological role as habitats for numerous species, highly productive areas and ecosystem services providers of important value to societies (Anthony et al., 2009; Newton et al., 2018). For this reason, some approaches try to overcome the challenge of integrating the management of coastal lagoons in the framework of global change while taking into account their vulnerabilities and potentialities (Lillebø et al., 2015; Vallejo, 1982; Anthony et al., 2009). In this context, the European Union considers coastal lagoons as a priority habitat type in its Habitats Directive (Directive 92/43/EEC) and includes several coastal lagoons in the Natura 2000 Network. Both directives seek to conserve biodiversity and habitats in natural ecosystems, with the main goal of restoring the ecological functionality of these systems and preserving their species richness (CCE, 1992; General Direction of Environment European Commission, 2017). Regarding the Mediterranean coastal area, urban and tourism development during the last decades of the 20th century have caused the disappearance or degradation of most of their coastal aquatic ecosystems. Thus, the restoration and recovery of the ecosystem services of these habitats are priorities in EU habitat management, which is why several Mediterranean coastal lagoons have benefited from financial assistance for restoration purposes, such as the Life Nature projects (Quintana et al., 2018).

Frequently, restoration projects mostly focus on eutrophication control or on keeping a permanent clear water phase to improve water quality (Scheffer et al., 1993). The restoration of an aquatic habitat can be a difficult process since the main ecological restoration goal to enable the functioning of all ecological processes in the restored system is not always fulfilled (Hobbs \& Harris, 2001). Possible causes of unsuccessful restoration may be a lack of understanding about the integrated ecological functioning of the ecosystem being restored or difficulties in dispersion and colonization by organisms. Evaluating the success of wetland restoration is often based on comparisons without available reference sites, previous studies or paleolimnological studies (Drake \& Naiman, 2000; Antón-Pardo et al., 2013). This is often why the basic restoration of ecological functions or just the recovery of an aquatic system are not achieved. Some studies have suggested that structural and functional restoration could be achieved in the medium term (decades), but some characteristics such as plant assemblages or biogeochemical functioning could take longer amounts of time (centuries) or stabilize in an alternative state to the natural or reference conditions (Moreno-Mateos et al., 2012 and 2015; Murcia et al., 2014). Although the management of restored habitats requires looking forward for this kind of long-term response to recovery, 
the need to wait for decades to assess the success (or failure) of a restoration seems ineffective. Thus, faster indicators that might reveal expected (or unexpected) behaviours of restored habitats immediately after restoration are needed.

Zooplankton assemblages respond rapidly to variations in environmental factors such as those caused by hydrological instability in Mediterranean coastal ecosystems (Quintana et al., 1998a, 1998b; Brucet et al., 2005; Badosa et al., 2006; Olmo et al., 2016). However, other factors or processes such as dispersal ability or priority effects also affect the colonization dynamics and, consequently, the zooplankton composition of restored wetlands (Bilton et al., 2001; Cohen \& Shurin, 2003; Ortells et al., 2012; Antón-Pardo et $a l ., 2016)$. These assemblages are dominated by passive dispersers that are characterized by a high dispersal ability by wind or bird transport (but see Incagnone et al., 2015); thus, they rapidly colonize new water bodies (Louette \& De Meester, 2005; Frisch et al., 2006; Olmo et al., 2012; Audet et al., 2013). In addition, egg banks can remain viable for decades or longer, but under the right environmental conditions, diapausing eggs can develop rapidly and conform to the zooplankton community together with new settlers (Brendonck \& De Meester, 2003). Therefore, the analysis of zooplankton composition could be useful to observe the effects of restoration in the short term, and dispersal along with egg bank establishment may be an effective method for species colonization in the restoration and recovery of ancient existing aquatic habitats.

We analysed the zooplankton composition in a recently restored Mediterranean coastal ecosystem, La Pletera, where new lagoons were created. La Pletera is a salt marsh affected by incomplete buildings intended for a residential estate in the late 1980s. A Life Nature project (Life Pletera, LIFE $13 \mathrm{NAT} / \mathrm{ES} / 001001$ ) has been recently developed with the aim of recovering the ecological functioning of the salt marsh by dismantling the unused urban features (breakwaters, promenade, accesses, and piles of debris) built during the construction process in the 1980s. Our aim was to compare the zooplankton community composition between the old existing lagoons and the newly created lagoons. Given the rapid dispersion of zooplankton communities and the possibility of a remaining egg bank, we hypothesize a similar zooplankton composition between the old and new lagoons.

\section{METHODS}

\section{Study area}

The study area is located in La Pletera, a Salicornia-dominated Mediterranean salt marsh area located in the Baix Ter Wetlands in the northeastern region of the Iberian Peninsula (Fig. 1). It is located between the urban centre of l'Estartit (Torroella de Montgrí, Girona) and the mouth of the River Ter. The site is one of the few marsh areas left on the Catalan coast, located immediately behind a foredune. This area presents a typical Mediterranean hydrological regime, and it is affected mainly by the presence of the sea. Water intrusions in the lagoons or flooding periods come from sudden sea storms, intense rainfall and groundwater flows. On the other hand, there are other long periods or confinement periods without surface water inputs, especially in summer and winter when the lagoons can even become dry (López-Flores et al., 2006; Badosa et al., 2006; Menció et al., 2017).

In 1987, partial urbanization modified the landscape of the zone, leading to the disappearance of some water bodies and the loss of the hydric connection (HC) among the remaining water bodies (Badosa et al., 2006; Quintana et al., 2009). Later, due to changes in urban classification promoted by the Council of Torroella de Montgrí, La Pletera was designated as a natural area and protected from building. Currently, the whole marsh of La Pletera is a natural park and is included in the Nature 2000 network (Quintana et al., 2009 and 2018). In the framework of a LIFE Restoration project (LIFE99NAT/E/006386), some new lagoons were built in 2002 that mainly sought to improve the populations of Iberian toothcarp (Aphanius iberus), an endemic fish of the Iberian Peninsula that is in danger of extinction (Doadrio et al., 2011), by means of the creation of new lagoons that would increase the number of habitat refuges for the endangered fish. These new lagoons joined the existing 
lagoons: Bassa del Pi and Bassa del Fra Ramon. In 2014, a second LIFE project began in the zone, project "LIFE-Pletera" (LIFE13NAT/ES/001001), with the objective, among others, of recover- ing the ecological functioning of the marshes (www.lifepletera.com). The infrastructures built during an old and unfinished urban process, such as breakwaters, promenades, accesses and accu-

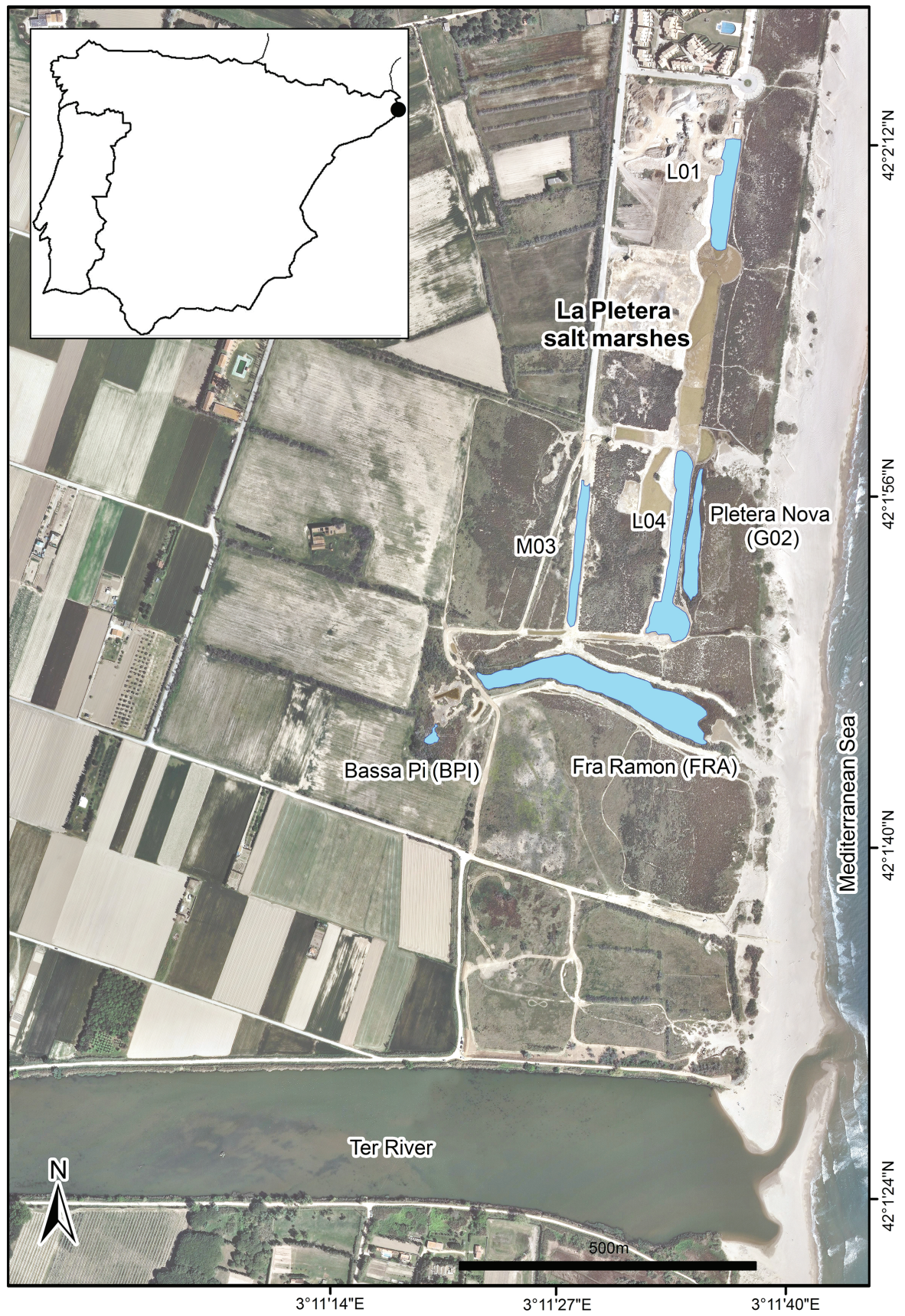

Figure 1. Map of the study site with the location of the six lagoons studied within La Pletera salt marshes. Mapa del área de estudio con la ubicación de las seis lagunas estudiadas dentro de la marisma de La Pletera. 
mulated debris, were removed and substituted by a set of new coastal water bodies. Limnological monitoring was carried out in the existing lagoons and in the new lagoons when they were created with the aim of comparing the different physical, chemical, hydrological and biological components.

\section{Field sampling and laboratory analyses}

Six lagoons were sampled: three were designated as "old" lagoons: Bassa del Pi (BPI), Fra Ramon (FRA), which are both natural lagoons, and Pletera Nova (G02), which was created in 2002. The other three were new lagoons that were created in 20161 and 2 months before the sampling started; these lagoons were dredged until reaching an elevation below sea level and were naturally filled with infiltration from the subsurface water from the saltmarshes: L04, L01 and M03 (Fig. 1). For details on the water circulation, see Menció et al. (2017).

Sampling was conducted monthly, covering an annual cycle starting in April 2016 through May 2017. The sampling covered a dry period (summer 2016), when the water level was at its minimum, and a flooding period (between autumn 2016 and spring 2017). During sea storm events, when the water level is highest, all water masses become connected, allowing displacement through the whole marsh. The hydric connections among the entire marsh (between the old and new lagoons) occurs when the water level increases to 1 metre above sea level (Pascual \& Martinoy, 2017). Thus, at this water level, dispersal via the water by organisms among the lagoons is feasible. After the creation of the new lagoons in April 2016, the water level in the marsh achieved a level of $1 \mathrm{~m}$ a.s.l. for the first time in October 2016.

A few days later, the water level decreased, and the different lagoons remained isolated again (Pascual \& Martinoy, 2017). Thus, we can divide our study time into two periods: before and after hydric connection. In terms of organisms' dispersal ability, these two periods differ in the fact that during the first period, any organism propagule

Table 1. Mean values and standard deviation (in brackets) of the environmental variables measured during the study period in the different lagoons aDO, deviation from $100 \%$ oxygen saturation. Valores medios y desviación estándar (en paréntesis) de las variables ambientales medidas durante el período de estudio en las diferentes lagunas aDO, desviación del $100 \%$ de saturación de oxígeno.

\begin{tabular}{|c|c|c|c|c|c|c|c|c|c|c|c|c|}
\hline \multirow{4}{*}{$\begin{array}{l}\text { Variable } \\
\text { Conductivity }(\mathrm{mS} / \mathrm{cm})\end{array}$} & \multicolumn{12}{|c|}{ Lagoons } \\
\hline & \multicolumn{6}{|l|}{ Old } & \multicolumn{6}{|l|}{ New } \\
\hline & \multicolumn{2}{|l|}{$\mathrm{BPI}$} & \multicolumn{2}{|l|}{ FRA } & \multicolumn{2}{|l|}{$\mathrm{GO2}$} & \multicolumn{2}{|l|}{ L04 } & \multicolumn{2}{|l|}{ L01 } & \multicolumn{2}{|l|}{ M03 } \\
\hline & 74.8 & $( \pm 54.7)$ & 63.2 & $( \pm 18.5)$ & 44.9 & $( \pm 18.6)$ & 36.2 & $( \pm 13.6)$ & 28.4 & $( \pm 8.9)$ & 54.5 & $( \pm 28.5)$ \\
\hline $\mathrm{pH}$ & 8.4 & $( \pm 0.3)$ & 8.5 & $( \pm 0.2)$ & 8.6 & $( \pm 0.3)$ & 8.7 & $( \pm 0.3)$ & 8.6 & $( \pm 0.3)$ & 8.8 & $( \pm 0.5)$ \\
\hline Temperature $(\stackrel{\circ}{\circ})$ & 16.7 & $( \pm 6.5)$ & 17.5 & $( \pm 6.2)$ & 16.7 & $( \pm 6.4)$ & 16.7 & $( \pm 6.2)$ & 16.8 & $( \pm 6.2)$ & 17.7 & $( \pm 6.8)$ \\
\hline aDO & 40.8 & $( \pm 30.5)$ & 48.1 & $( \pm 35.2)$ & 39.4 & $( \pm 51.7)$ & 9.3 & $( \pm 10.3)$ & 14.9 & $( \pm 21.9)$ & 30.2 & $( \pm 50.1)$ \\
\hline $\mathrm{NH}_{4}^{+}(\mathrm{mg} / \mathrm{L})$ & 1.9 & $( \pm 3.8)$ & 0.3 & $( \pm 0.3)$ & 0.3 & $( \pm 0.5)$ & 0.2 & $( \pm 0.4)$ & 0.2 & $( \pm 0.3)$ & 0.1 & $( \pm 0.1)$ \\
\hline $\mathrm{NO}_{2}^{-}(\mathrm{mg} / \mathrm{L})$ & 0.00 & $5( \pm 0.005)$ & 0.004 & $( \pm 0.001)$ & 0.004 & $7( \pm 0.001)$ & 0.006 & $5( \pm 0.009)$ & 0.004 & $4( \pm 0.0)$ & 0.00 & $4( \pm 0.0)$ \\
\hline $\mathrm{NO}_{3}^{-}(\mathrm{mg} / \mathrm{L})$ & 0.05 & $( \pm 0.1)$ & 0.02 & $( \pm 0.0)$ & 0.02 & $( \pm 0.0)$ & 0.03 & $( \pm 0.006)$ & 0.02 & $( \pm 0.0)$ & 0.02 & $( \pm 0.0)$ \\
\hline $\mathrm{PO}_{4}^{-3}(\mathrm{mg} / \mathrm{L})$ & 0.1 & $( \pm 0.1)$ & 0.06 & $( \pm 0.05)$ & 0.03 & $( \pm 0.04)$ & 0.009 & $( \pm 0.01)$ & 0.02 & $( \pm 0.03)$ & 0.01 & $( \pm 0.01)$ \\
\hline $\mathrm{TP}$ (mg P/L) & 0.3 & $( \pm 0.3)$ & 0.3 & $( \pm 0.2)$ & 0.2 & $( \pm 0.2)$ & 0.1 & $( \pm 0.03)$ & 0.1 & $( \pm 0.03)$ & 0.2 & $( \pm 0.1)$ \\
\hline TOC (mg C/L) & 103.2 & $( \pm 64.3)$ & 40.1 & $( \pm 18.3)$ & 37.0 & $( \pm 18.8)$ & 30.3 & $( \pm 11.8)$ & 39.1 & $( \pm 22.2)$ & 35.2 & $( \pm 12.6)$ \\
\hline TIC (mg C/L) & 87.6 & $( \pm 24.6)$ & 51.2 & $( \pm 8.9)$ & 58.8 & $( \pm 14.5)$ & 57.5 & $( \pm 13.1)$ & 64.1 & $( \pm 24.2)$ & 57.0 & $( \pm 19.8)$ \\
\hline Water level (cm a.s.I.) & 35.2 & $( \pm 30.9)$ & 29.9 & $( \pm 23.4)$ & 33.1 & $( \pm 20.6)$ & 34.7 & $( \pm 21.1)$ & 35.6 & $( \pm 20.7)$ & 38.5 & $( \pm 35.6)$ \\
\hline
\end{tabular}


could not reach the new lagoons from the old lagoons via the water.

Water samples were taken to integrate, as much as possible, the entire lagoon. The samples were taken on the surface or up to a maximum depth of $50 \mathrm{~cm}$. The temperature, electrical conductivity (EC25), $\mathrm{pH}$ and dissolved oxygen were taken in situ using a Hach HQ30d portable multiparameter probe. The water level (WL) was measured as the height in $\mathrm{cm}$ above or below the average sea level by means of levels installed in the lagoons. The average sea level was obtained from the Meteorological Station of L'Estartit and refers to the average sea level from 1990 - 1995 (Pascual \& Martinoy, 2017). A total of $125 \mathrm{ml}$ of unfiltered sample was collected to analyse the total nutrients: total nitrogen (TN), total phosphorus (TP), total organic carbon (TOC) and total inorganic carbon (TIC). The water filtered by Whatman GFF filters was collected to analyse the dissolved nutrients: ammonium $\left(\mathrm{NH}_{4}^{+}\right)$, nitrate $\left(\mathrm{NO}_{3}^{-}\right)$, nitrite $\left(\mathrm{NO}_{2}^{-}\right)$, soluble reactive phosphate $\left(\mathrm{PO}_{4}^{-3}\right)$, dissolved organic carbon (DOC) and dissolved inorganic carbon (DIC). The concentration of organic nitrogen and phosphorus were obtained by subtracting the inorganic forms from the total samples were frozen until analysis. These analyses were carried out following standard methods (APHA, 1992).

The zooplankton samples were obtained after in situ filtration of $5 \mathrm{~L}$ of water through a $50 \mu \mathrm{m}$ net fixed in $4 \%$ formalin. To identify, count and measure the zooplankton taxa, an inverted microscope was used. All the calculations, plots and statistical analyses in this work were performed with these $50 \mu \mathrm{m}$ samples. The organisms in these samples were identified at the lowest taxonomical level possible without specimen manipulation. Thus, most of the taxa were not distinguished at the species level in the statistical analyses. The copepods were distinguished as calanoids, cyclopoids and harpacticoids as well as by their stages (nauplii, copepodites and adults). For each taxon, 25 individuals were measured to estimate the organisms' body size and biomas, measured in dry weight (DW). Crustacean biomass has been estimated from the allometric relationship between weight and body length, and using pre-established equations. The rotifer and ciliate biomass was calculated by converting the volume into a dry weight (Ruttner-Kolisko, 1977; Malley et al., 1989; Putt \& Stoecker, 1989). The zooplankton in these ecosystems are normally dominated by few species of copepod that represent most of the biomass present in the lagoons (Quintana et al., 1998b; Brucet et al., 2005). To corroborate this pattern and determine which copepod species were present, additional seasonal samples were collected. In these samples, high concentrations of adult copepods were captured, which allowed us to identify the copepods at the species level. This additional sample was collected using a 20 cm-diameter dipnet (mesh size: $250 \mu \mathrm{m}$ ) and 20 sweeps (a push half a metre long) in different habitats of the lagoon. In each sample, 24 specimens of each copepods group were determined at the species level.

\section{Data analysis}

To analyse the differences among lagoons in their water composition, a PCA analysis was performed. All the environmental variables except $\mathrm{pH}$ were $\log$ transformed. The oxygen concentration was determined by how far it was from $100 \%$ saturation and the absolute [\%] deviation from saturation was measured [aDO = abs $|100-\% 0|]$, as proposed by Vollenweider et al. (1998), and this value was used in the PCA (aDO) instead of the rough oxygen concentration. The season, age of the lagoons (old or new) and the hydric connection (before and after) were added as categorical variables to determine the differences among them. To check the significance of the results, a between-group analysis coupled with the multivariate analysis (the dudi.pca function in R studio), and the calculation of the inertia for each zooplankton group (the dudi.coa function in R studio) was performed.

To determine differences in the zooplankton composition among the lagoons, non-parametric multi-dimensional scaling (NMDS) was performed using the biomass of the different identified zooplankton taxa. The adult and copepodite stages of the calanoids, cyclopoids or harpacticoids were grouped, differentiating them from the nauplii stages. The Bray-Curtis similar- 
Table 2. List of zooplankton taxa found in La Pletera salt marshes and their mean densities, with the standard deviation (in brackets) for each lagoon ( $\mu \mathrm{g}$ DW/L). Brachionus quadridentatus, Ciliophora and Colurella sp. were not included in the statistical analyses. The taxa codes are in brackets. Listado de taxones de zooplancton encontrados en la marisma de La Pletera y sus densidades medias con la desviación estándar (entre paréntesis) para cada laguna ( $\mu \mathrm{g} \mathrm{DW} / \mathrm{L}$ ). Brachionus quadridentatus, Ciliophora y Colurella sp. no fueron incluidos en los análisis estadísticos. Entre paréntesis, código de los taxones.

\begin{tabular}{|c|c|c|c|c|c|c|}
\hline \multirow[t]{3}{*}{ Taxa } & \multicolumn{6}{|c|}{ Lagoons } \\
\hline & \multicolumn{3}{|l|}{ Old } & \multicolumn{3}{|l|}{ New } \\
\hline & BPI & FRA & $\mathrm{G02}$ & L04 & L01 & M03 \\
\hline \multicolumn{7}{|l|}{ Copepoda } \\
\hline Calanoida (adults and copepodites) & 1772.3 & 340.1 & 5703.7 & 216.5 & 288.8 & 297.9 \\
\hline (A_C_CAL) & $( \pm 3482.0)$ & $( \pm 863.7)$ & $( \pm 19445.6)$ & $( \pm 753.6)$ & $( \pm 814.7)$ & $( \pm 762.6)$ \\
\hline Cyclopoida (adults and copepodites) & 0.5 & 0.8 & 0.5 & 0.2 & 0.4 & 1.6 \\
\hline (A_C_CYC) & $( \pm 1.2)$ & $( \pm 2.5)$ & $( \pm 1.7)$ & $( \pm 0.5)$ & $( \pm 0.8)$ & $( \pm 3.6)$ \\
\hline Harpacticoida (adults and copepodites) & 0.2 & 4.0 & 6.4 & 0.1 & 0.2 & 0.5 \\
\hline (A_C_HAR) & $( \pm 0.9)$ & $( \pm 13.1)$ & $( \pm 17.9)$ & $( \pm 0.1)$ & $( \pm 0.6)$ & $( \pm 1.2)$ \\
\hline Calanoida (nauplii) & 41.8 & 302.0 & 78.7 & 76.1 & 54.6 & 55.7 \\
\hline (N_CAL) & $( \pm 80.1)$ & $( \pm 983.5)$ & $( \pm 184.8)$ & $( \pm 280.9)$ & $( \pm 185.1)$ & $( \pm 191.4)$ \\
\hline Cyclopoida (nauplii) & 1.0 & 1.8 & 3.1 & 2.0 & 0.7 & 1.1 \\
\hline (N_CYC) & $( \pm 1.7)$ & $( \pm 4.6)$ & $( \pm 6.4)$ & $( \pm 6.4)$ & $( \pm 0.8)$ & $( \pm 2.0)$ \\
\hline Harpacticoida (nauplii) & 0.003 & 0.03 & 0.005 & 0.005 & 0.002 & \\
\hline (N_HAR) & $( \pm 0.01)$ & $( \pm 0.08)$ & $( \pm 0.01)$ & $( \pm 0.01)$ & $( \pm 0.004)$ & \\
\hline \multicolumn{7}{|l|}{ Rotifera } \\
\hline Asplanchna sp. (ASP_SP) & $\begin{array}{r}1.5 \\
( \pm 5.5)\end{array}$ & - & - & - & - & - \\
\hline Brachionus nlicatilis (BRA PI) & 4428.3 & 344.0 & 104.9 & 26.9 & 53.2 & 566.9 \\
\hline Bracnionus plicantis (BRA_PLI) & $( \pm 13963.2)$ & $( \pm 1233.7)$ & $( \pm 219.9)$ & $( \pm 92.4)$ & $( \pm 125.9)$ & $( \pm 2004.6)$ \\
\hline Brachionus quadridentatus (BRA_QUA) & - & - & $\begin{array}{r}0.004 \\
( \pm 0.01)\end{array}$ & - & - & - \\
\hline Colurella sp. (CLR_SP) & - & - & $\begin{array}{r}0.0003 \\
( \pm 0.001)\end{array}$ & - & - & - \\
\hline Synchaeta sp. (SYN SP) & 0.2 & 0.0002 & 1.0 & 0.8 & 1.8 & . \\
\hline & $( \pm 0.6)$ & $( \pm 0.0006)$ & $( \pm 3.6)$ & $( \pm 2.9)$ & $( \pm 6.8)$ & \\
\hline Testudinella clypeata (TES_CLY) & - & - & $\begin{array}{r}0.1 \\
( \pm 0.4)\end{array}$ & - & $\begin{array}{r}0.0006 \\
( \pm 0.002)\end{array}$ & - \\
\hline \multicolumn{7}{|l|}{ Protozoa } \\
\hline Ciliophora (CIL_SP) & - & $\begin{array}{r}0.006 \\
( \pm 0.02)\end{array}$ & - & - & - & - \\
\hline
\end{tabular}

ity coefficient was calculated as the resemblance measure. The zooplankton data were transformed using the Hellinger transformation (Legendre \& Gallagher, 2001). To detect possible associations between the patterns of species composition and the environmental variables, we used the 'envfit' function in the 'vegan' package in $\mathrm{R}$, and statistical significance was evaluated by 999 random permutations. Finally, we also made a variance partitioning to determine the relative influence of the environmental variables (only including variables significantly related to zooplankton that were identified using a forward selection procedure), lagoon age and hydric connection on the zooplankton composition using zooplankton composition as a response matrix and the other variables as predictor matrices (Borcard et al., 1992; Legendre \& Legendre, 1998). We use the vegan package (Oksanen et al., 2009) of the $\mathrm{R}$ language ( $\mathrm{R}$ development 
Core Team, 2008). All the calculations and statistical analyses were performed with $R$ Studio 3.4.0 for Windows.

\section{RESULTS}

\section{Environmental variables}

The data measured in situ showed that there were no differences in water level between the old and new lagoons, with high variability and marked temporal patterns in each lagoon (Fig. 2a). The maximum increase started in October 2016, coinciding with the beginning of the flooding period, which was the first time the newly created lagoons connected with the existing lagoons (see methods). The conductivity was higher in the old lagoons until October 2016, when lagoons were connected (Fig. 2b). After that time, the conductivity values were similar in all the lagoons. The conductivity increased in the dry seasons, sometimes reaching or exceeding the seawater conductivity in the old lagoons, especially in Bassa Pi (BPI) and Fra Ramon (FRA), with maximum values of $193.5 \mathrm{mS} / \mathrm{cm}$ and $91.5 \mathrm{mS} / \mathrm{cm}$, respectively. In the flooding period, the conductivity tended to decrease, with the lowest conductivity values reached in February $(12.84 \mathrm{mS} / \mathrm{cm}$ in BPI and $18.82 \mathrm{mS} / \mathrm{cm}$ in L01). Table 1 summarizes the main environmental variables and their variability in the old (BPI, FRA and G02) and new lagoons (L04, L01 and M03).

The first two axes of the PCA analysis, which include the environmental variables, accounted for $48 \%$ of the total variance (Fig. 3a). The first PCA axis (32\%) correlated negatively with water level and positively with conductivity, temperature and $\mathrm{aDO}$. This means that this axis was related to the hydrological regime (flooding - confinement). The second axis (16\%) was related to the inorganic forms of $\mathrm{N}$ and $\mathrm{C}$. It was positively correlated with $\mathrm{NO}_{3}^{-}, \mathrm{NO}_{2}^{-}$and DIC and negatively correlated with $\mathrm{pH}$ and particulate carbon (PIC and POC). The sample positions in the PCA plot differed (between-group analyses: $p<0.001)$ before and after the hydric connection (Fig. 3b). The samples taken before the hydric connection were more related to confinement and to higher organic nutrient content (higher PCA1 and PCA2 values), while the samples taken after the hydric connection were more related to flooding and to higher concentrations of inorganic nitrogen (lower PCA1 and PCA2 values). The sample positions in the PCA plot also differed (between-group analyses: $p<0.001$ ) between the old and new
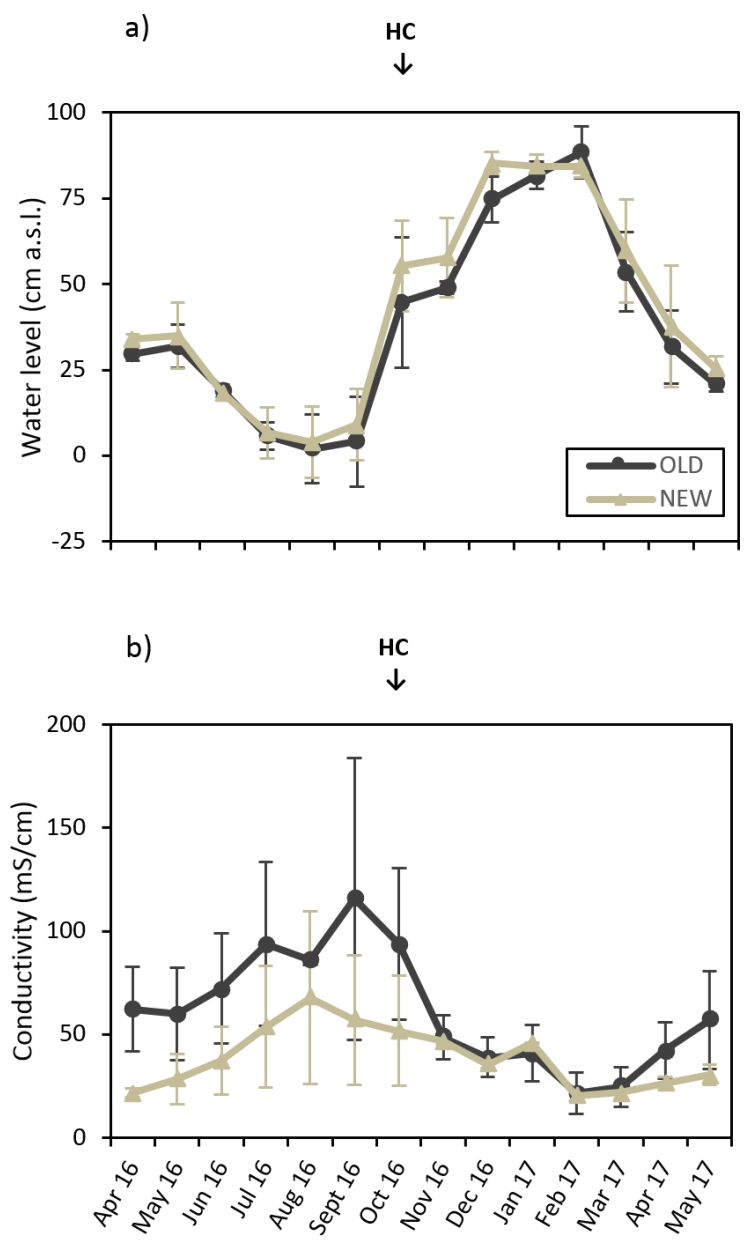

Figure 2. (a) Changes in the average water level (cm above or below sea level) of the studied lagoons (old and new) during the hydrological cycle 2016-2017. HC indicates the hydric connection for the first time. (b) Changes in conductivity $(\mathrm{mS} / \mathrm{cm})$ in the same lagoons (old and new) during the same period. (a) Cambios en el promedio del nivel de agua (cm por encima o debajo del nivel del mar) de las lagunas de estudio (viejas y nuevas), durante el ciclo hidrológico 2016-2017. HC indica la conexión hídrica por primera vez. (b) Cambios en la conductividad ( $\mathrm{mS} / \mathrm{cm}$ ) en las mismas lagunas (viejas y nuevas), durante el mismo período. 
lagoons, with higher PCA1 values in the old lagoons (Fig. 3c). The samples clustered by season showed significant differences, separating the samples from the dry periods (summer 2016) from those from the flooding season (autumn 2016 and winter 2016) $(p<0.001$, in both cases). The springs (2016 and 2017) compared to winter also showed a significant difference ( $p<0.001$, in both cases). However, there was an interannual difference between spring 2016 and $2017(p<0.05)$ (Fig. 3d).
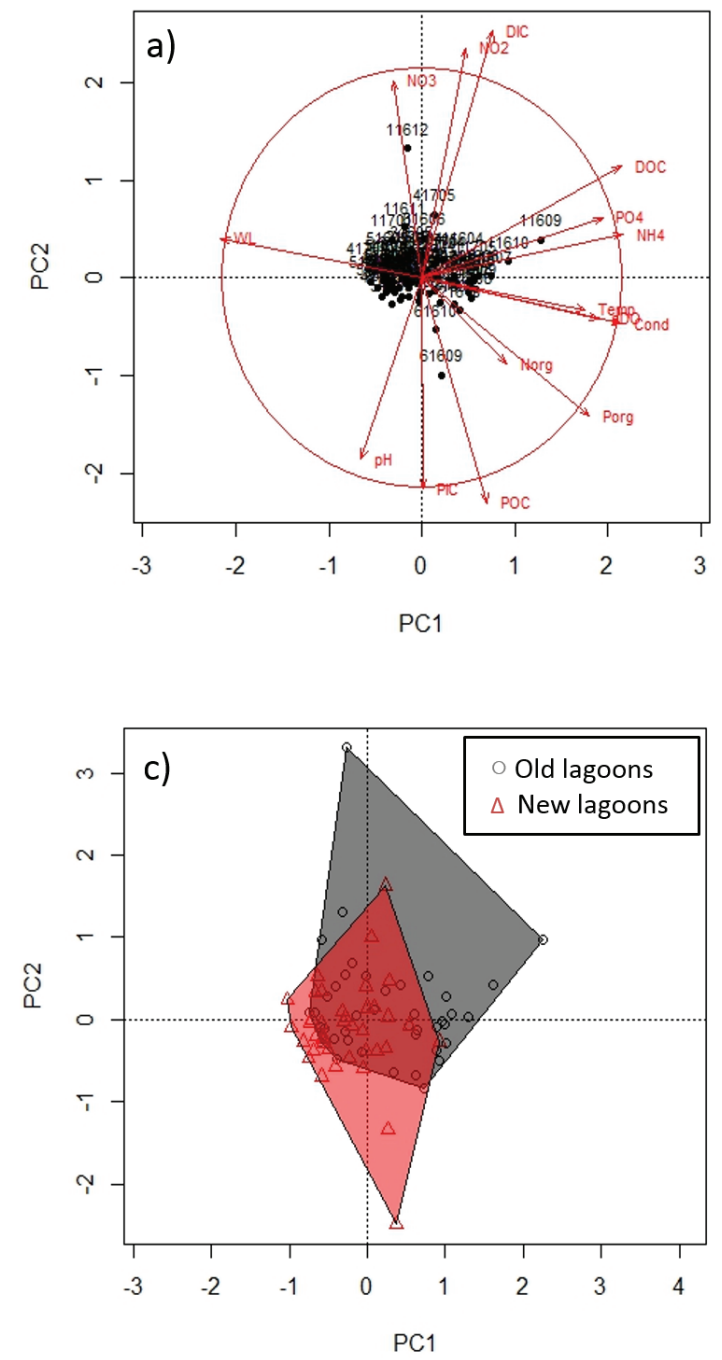

\section{Zooplankton community structure and com- position}

Thirteen zooplankton taxa were identified in the samples (Table 2); three of these taxa were removed from the statistical analyses due to their low presence and abundance (those that appear in only one sample and with abundance below 1.0 $\mu \mathrm{gDW} / \mathrm{L})$ : Colurella sp, Ciliophora and Brachionus quadridentatus. The copepods were dominated by Eurytemora velox in the calanoid
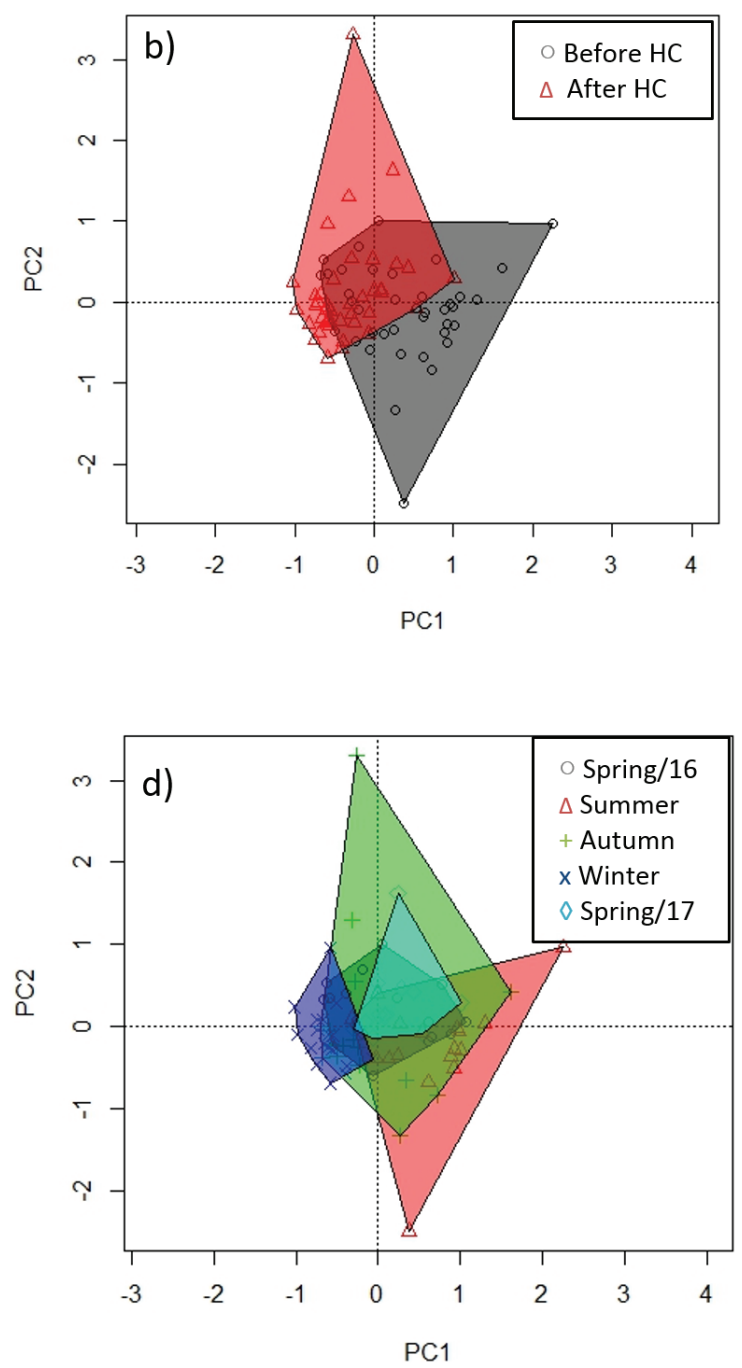

Figure 3. (a) PCA ordination diagram showing the distribution of the samples in relation to the environmental variables in the space represented by the first two axes. PCA polygons: (b) hydric connection [HC], (c) age and (d) season. (a) Diagrama de ordenación PCA con la distribución de las muestras en relación con las variables ambientales representados en el espacio de los dos ejes principales. Poligonos PCA: (b) Conexión Hidrica [HC], (c) Edady (d) Estación. 


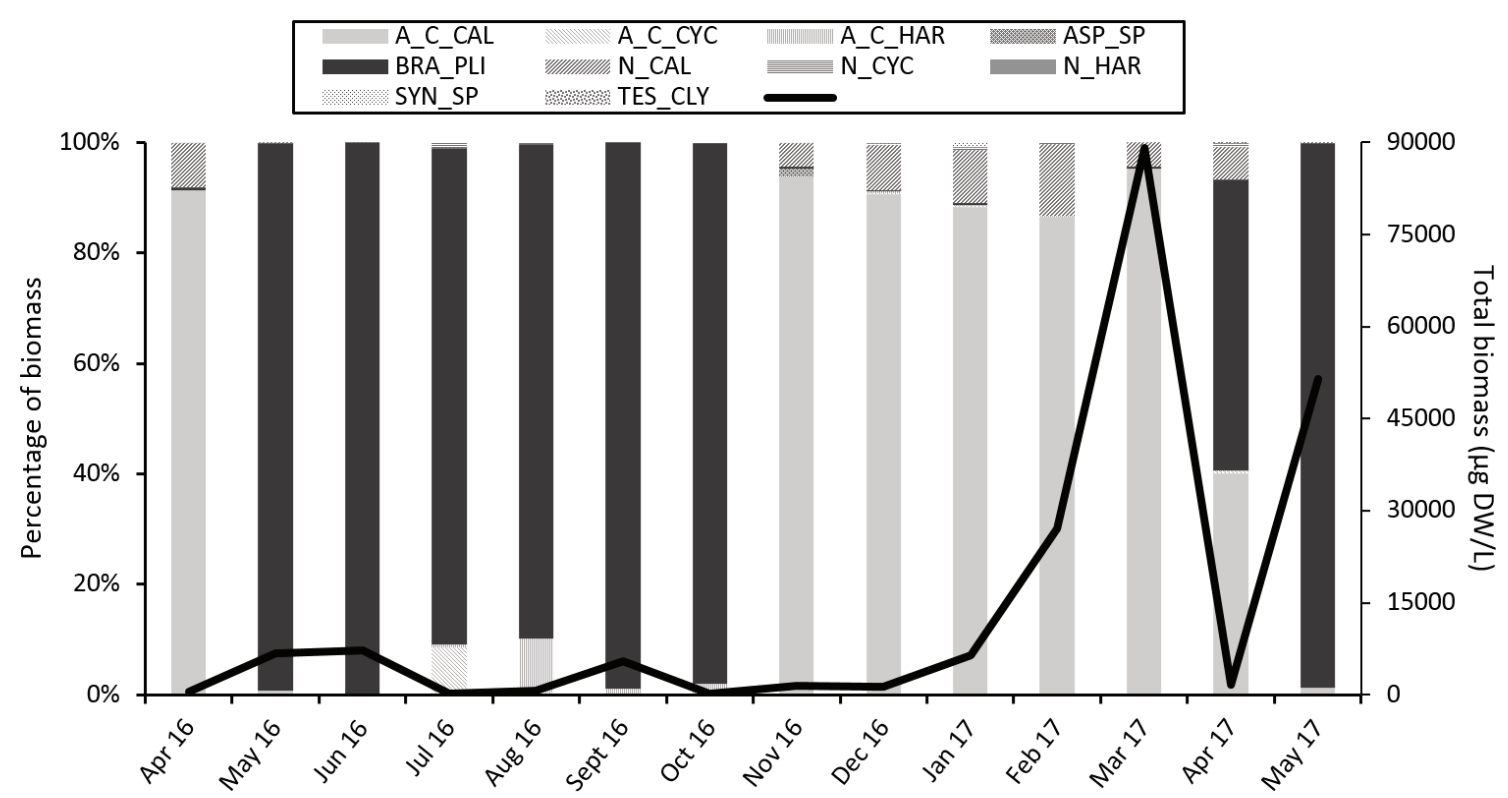

Figure 4. Relative abundance (in \%) of the zooplankton species during the study period from 2016-2017 in the six lagoons. Total zooplankton abundance ( $\mu \mathrm{g} \mathrm{DW} / \mathrm{L})$ is shown by the solid line on the right axis of the plot. Abundancia relativa (en \%) de las especies de zooplancton durante el periodo de estudio 2016-2017 en las seis lagunas. La abundancia total del zooplancton ( $\mu$ g DW/L) se muestra en línea gruesa en el eje derecho del gráfico.

adults (87\% of the individuals examined), Halicyclops rotundipes in the cyclopoids $(86 \%)$ and Cletocamptus confluens in the harpacticoids (more than $66 \%$ ). The most represented taxa were calanoid adults and copepodites, with the highest average density of $5700 \mu \mathrm{g}$ DW/L corresponding to G02, and Brachionus plicatilis, with the highest average density of $4420 \mu \mathrm{g}$ DW/L corresponding to BPI (Table 2). These two groups marked the temporal pattern in species composition. The calanoids dominated the community in the flooding period (up to $80 \%$ of the total zooplankton biomass), while $B$. plicatilis dominated in the dry period (up to $85 \%$ biomass) (Fig. 4). April 2017 was the only month when there was no clear dominance, but this time point divides the organisms' density by a similar percentage (approximately $45 \%$ ). In March 2017, the zooplankton biomass peaked, reaching a maximum of $89200 \mu \mathrm{g} \mathrm{DW} / \mathrm{L}$, followed by a strong decrease and return to the average abundance values (3040 $\mu \mathrm{g}$ DW/L) (Fig. 4). The calanoid nauplii had a lower density than the previous two taxa, reaching a mean density of
$330 \mu \mathrm{g}$ DW/L in FRA. Their maximum densities coincided with the dominance of the calanoid adult stages (from November 2016 to April 2017) (Fig. 4).

The results showed differences among the lagoons in total zooplankton biomass. The old lagoons had a higher density, with a maximum value of $59200 \mu \mathrm{g} \mathrm{DW} / \mathrm{L}$, while the new lagoons reached the density maximum value of $7300 \mu \mathrm{g}$ DW/L (Fig. 5a). Lagoons BPI and G02 reached the highest densities (81 100 and $82600 \mu \mathrm{g}$ $\mathrm{DW} / \mathrm{L}$, respectively), but their compositions were different. In G02, calanoids dominated the community, reaching $96.7 \%$, while in BPI, these organisms represented $28.4 \%$ of the zooplankton community, with $70.9 \%$ dominated by $B$. plicatilis (Fig. 5b). The other lagoons had a similar total biomass, although in order of density, FRA reached $13900 \mu \mathrm{g}$ DW/L with a similar proportion represented by calanoids (adults and copepodites), the rotifer $B$. plicatilis and the calanoid nauplii (Fig. 5). Within the new lagoons, M03 had a total zooplankton biomass of 12000 $\mu \mathrm{g} \mathrm{DW} / \mathrm{L}$, with a higher percentage of $B$. 


\begin{tabular}{|c|c|c|c|}
\hline $\begin{array}{l}\text { A_C_CAL } \\
\text { BRA_PLI } \\
\text { SYN_SP }\end{array}$ & $\begin{array}{l}\text { A_C_CYC } \\
\text { YIIIIIIIIIIII, N_CAL } \\
\text { TES_CLY }\end{array}$ & 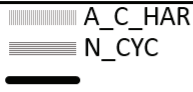 & $\begin{array}{r}\text { ASP_SP } \\
\text { N_HAR }\end{array}$ \\
\hline
\end{tabular}
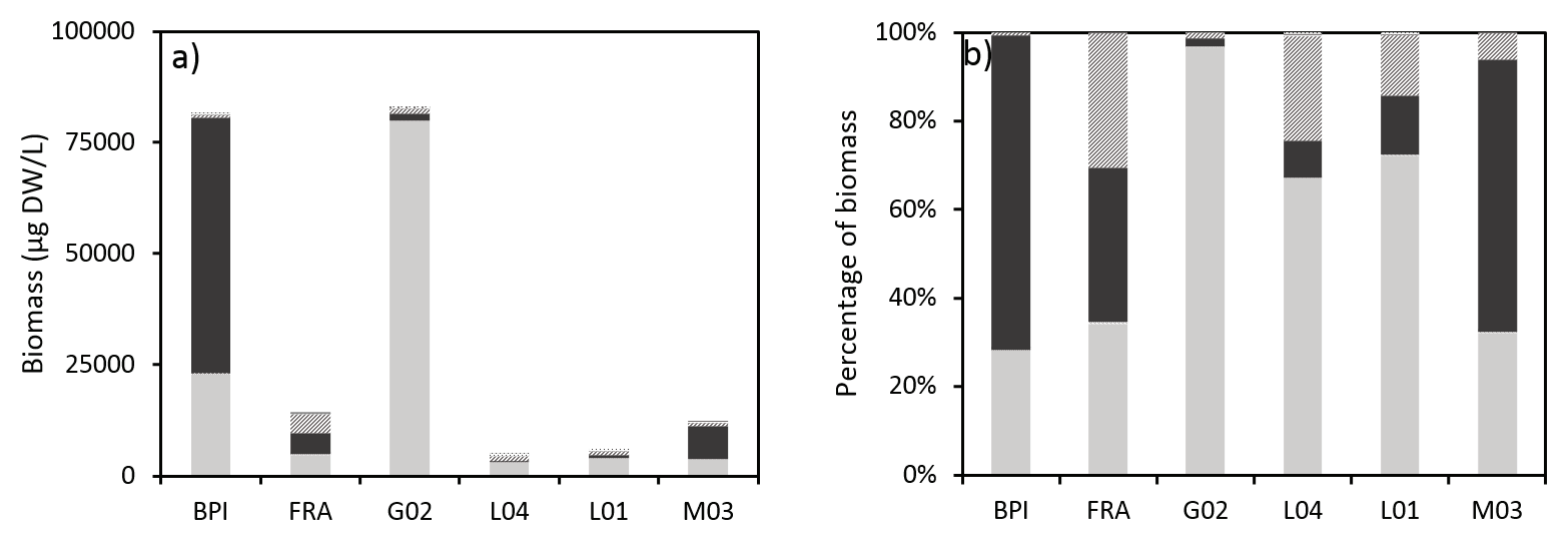

Figure 5. (a) Total biomass ( $\mu \mathrm{g} \mathrm{DW} / \mathrm{L}$ ) of the zooplankton composition in each lagoon [average of all months]. (b) Relative biomass percentage of the different zooplankton groups in each lagoon [average of all months]. (a) Biomasa total ( $\mu \mathrm{g}$ DW/L) del zooplancton en cada laguna [promedio de todos los meses]. (b) Porcentaje de biomasa relativo de los diferentes grupos zooplanctónicos en cada laguna [promedio de todos los meses].

plicatilis $(61.37 \%)$ than calanoids $(32.25 \%)$. The other two new lagoons, L04 and L01, had similar total zooplankton densities (4520 and $5600 \mu \mathrm{g}$ $\mathrm{DW} / \mathrm{L}$, respectively) and the same composition, with a dominance by calanoids (Fig. 5b).

The NMDS analysis results including the zooplankton taxa are listed in Table 2 and summarized in Fig. 6, showing a similar pattern to the one observed for the environmental variables (PCA results). The significant variables were the water level (in the lowest coordinates) $(p<$ 0.001), which represented the flooding period dominated by the calanoids (all stages) and the rotifers Testudinella sp., Asplanchna sp. and Synchaeta sp. On the other hand, the samples with the highest coordinates were collected during the dry period when the conductivity ( $p<$ $0.001)$ and temperature $(p<0.01)$ were highest. Coinciding with the maximum values of $\mathrm{aDO}(p$ $<0.01), \mathrm{NH}_{4}+(p<0.001), \operatorname{SRP}(p<0.01)$ and the organic nutrients such as organic phosphorus $(p<$ $0.001)$, organic nitrogen $(p<0.05)$ and DOC $(p<$ $0.001), B$. plicatilis dominated the community and had fewer cyclopoids and harpacticoids (adults and copepodites stages) (Fig. 6a).

Contrary to the results obtained in the PCA with the environmental variables, there were no significant differences in the zooplankton species composition. The sample positions in the NMDS results were not significantly different for the hydric connection (before and after) or the lagoon age (old and new lagoons) (Fig. 6b and 6c). Fig. 6b shows a strong overlap of the samples before and after the hydric connection, with the before-connection polygon surface including all the data of the after-connection polygon. The same situation occurred for the lagoon age, where the old lagoons overlapped the new lagoons (Fig. 6c). The seasons showed a certain degree of overlap among them, although the Monte Carlo test showed that there were some significant differences between winter and summer (flooding and dry period) $(p<0.001)$ (Fig. 6d). Summer and autumn also showed differences $(p<0.01)$, and winter presented differences with spring $2016(p<0.001)$ and spring $2017(p<$ $0.001)$. Finally, the NMDS polygon results did not show a significant difference between the spring 2016 samples and spring 2017 samples, which differed from the result regarding the environmental variables (Fig. 5d).

The variance partitioning analysis showed that unique environmental variables explained $16 \%$ of the variance in the zooplankton composition $(p<0.001)$. The environmental variables 
a)

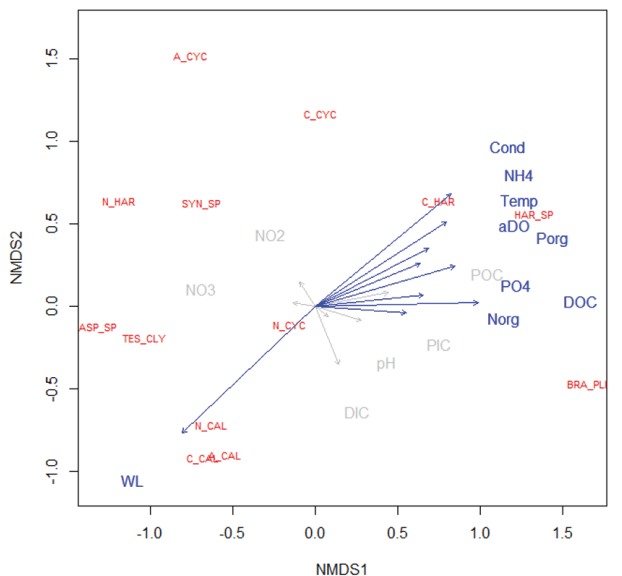

b)

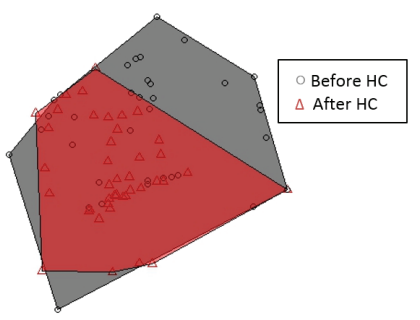

c)
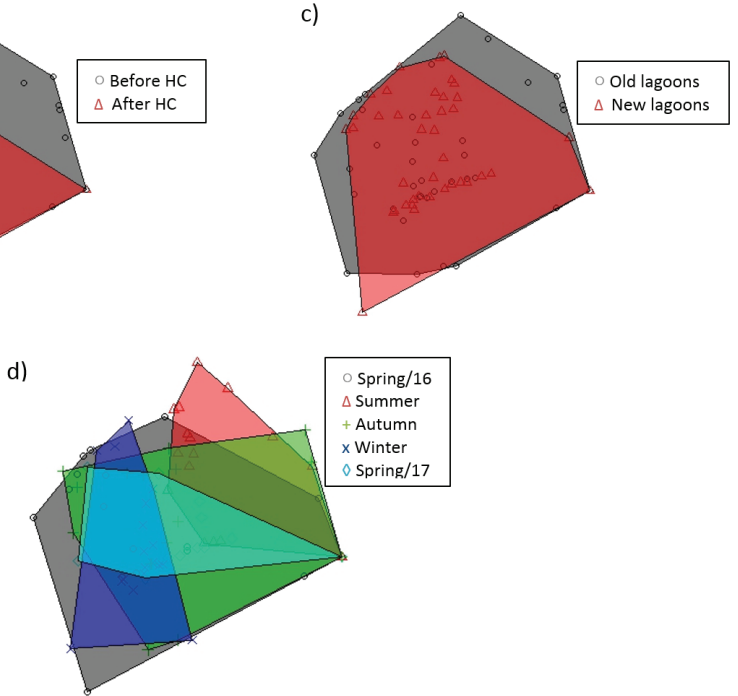

Figure 6. (a) NMDS plot, based on Bray-Curtis similarity, showing the distribution of samples and the zooplankton taxa (see taxa codes in Table 2) in relation to the environmental variables in the space. The polygons discriminate the samples by (b) hydric connection [HC], (c) age and (d) season. (a) Gráfico NMDS, basado en los criterios de similitud de Bray-Curtis, mostrando la distribución de las muestras y los taxones de zooplancton (ver códigos de taxones en la Tabla 2) en relación con las variables ambientales. Los polígonos discriminan muestras por: (b) Conexión hídrica [HC], (c) Edady (d) Temporada.

sharing effects with the hydric connection explained $31 \%$. The unique effects of lagoon age and hydric connection had no significant contribution to the variability in the zooplankton composition. Finally, $53 \%$ of the variance remained unexplained.

\section{DISCUSSION}

The zooplankton composition in La Pletera is dominated by euryhaline species that are adapted to the high salinity fluctuations that characterize these ecosystems, which is similar to that found in other Mediterranean coastal environments with fluctuating environmental conditions (Cognetti \& Maltagliati, 2000; Ramdani et al., 2001; Antón-Pardo \& Armengol, 2010). Species diversity is always low, with some single taxa dominating the zooplankton community ( $>80 \%$ dominance in biomass in at least 55 of the 82 samples analysed). This coincides with previous studies developed in these confined coastal marshes and in similar marshes (Quintana et al., 1998b; Brucet et al., 2005; Badosa et al., 2006). We found 
higher differences among seasons, even in a single lagoon, than between the old and new lagoons. The seasonal variability in the zooplankton composition in La Pletera follows the flooding - confinement pattern that drives nutrient dynamics and species composition in this type of habitat (Brucet et al., 2005): Synchaeta appears immediately after marine water intrusion; cyclopoid copepods appear in the middle season with a slight preference of the nauplii stages over the adult stages for flooding conditions; calanoid copepods dominate during stable winter-spring hydrological conditions; and B. plicatilis dominates during the dry period, with high confinement and frequent hypertrophic events due to the tolerance of this species to low oxygen concentration (Miracle et al., 1987). Harpacticoid copepods have a brief dominance when the water level is low, but their resistance to severe confinement conditions is much lower than that of $B$. plicatilis (Moreira et al., 1982). In our case, this pattern appears to be simpler than that observed by Quintana et al. (1998b) and Brucet et al. (2005). At least in part, this could be attributable to the sampling frequency, which was weekly in the cited references and monthly in this study.

The PCA results using the environmental variables showed some differences between the old and new lagoons. The total nutrients and organic matter concentrations were higher in the old lagoons, suggesting a progressive accumulation during successive flooding - confinement events over the years (Badosa et al., 2006). However, we did not find significant differences between the old and new lagoons in the zooplankton NMDS results, suggesting a fast response of zooplankton after lagoon creation. Similar fast colonization has been reported in other studies (Badosa et al., 2010; Antón-Pardo et al., 2013). The environmental variables and hydric connection explained $47 \%$ of the variance in the zooplankton composition. The remaining $53 \%$ unexplained variance could be the consequence of several factors, such as hydrological parameters, "bottom-up" effects by other environmental variables that were not measured or "top-down" control by predators (Kelly et al., 2002; López-Flores et al., 2006; West et al., 2009; Compte et al., 2012).
Four different mechanisms may determine the zooplankton composition in newly created lagoons: 1) the dispersal ability and arrival of new colonizers from nearby water bodies, 2) the hatching of the egg bank present in the sediment of the new lagoons, 3) the physical and chemical composition of the new lagoons and 4) top-down control by predators. Zooplankton species such as other small organisms (i.e., small propagules) have been considered to have virtually no dispersal limitation according to the so-called 'cosmopolitan paradigm' or 'everything is everywhere' hypothesis (O'Malley 2007). This paradigm has been supported by (1) the rapid colonization of newly created or restored waterbodies by these organisms (e.g., Louette \& De Meester, 2005; Olmo et al., 2012; Audet et al., 2013); (2) the high potential for passive long-range dispersal of organisms producing resting stages (Louette \& De Meester, 2005); or (3) cysts being efficiently transported by physical or biological vectors (e.g., Bohonak \& Whiteman, 1999; Vanschoenwinkel et al., 2009). However, the generality of the cosmopolitan paradigm is under discussion (Incagnone et al., 2015 and references therein), since: (1) spatial structures have been observed in plankton metacommunities even in ponds that were affected by similar environmental variables (Jenkins \& Buikema, 1998); (2) high degrees of endemism have been reported for microcrustaceans (Marrone et al., 2013); and (3) lower-than-expected genetic flows have been described for high-dispersal species (De Meester et al., 2002). In La Pletera salt marshes, there is a short distance between the new lagoons and the existing ones, facilitating the colonization of the new lagoons. Antón-Pardo et al. (2016) mention that the short distance among the lagoons and the apparent absence of geographical barriers facilitate the occurrence of zooplankton dispersal vectors (e.g., waterbirds, wind or humans). Other studies performed on permanent and temporary lagoons showed a similar pattern to that found in the La Pletera salt marshes (Cottenie et al., 2003; Audet et al., 2013; Antón-Pardo et al., 2016).

The lack of significant differences in zooplankton composition between the old and new lagoons before and after hydric connection suggests that zooplankton dispersion via hydroco- 
ra is not relevant in the early colonization of new lagoons. On the other hand, the hatching of the egg bank resting on the sediment filled with manmade debris during the last decades but removed during the restoration actions seems to be important. In fact, the new lagoons were built on what was a uniform marsh only a few decades ago. Thus, the new bottoms of the restored lagoons must be rich in resting eggs, which easily hatch after several decades of diapause (De Stasio, 1990; Alekseev \& Starobogatov, 1996; Hairston \& Cáceres, 1996). Egg banks are frequently dense in previously filled ponds, providing great opportunities for hatching immediately after restoration (Antón-Pardo \& Armengol, 2010). Several studies support the importance of egg banks in facilitating colonization by zooplankton (Keller \& Yan, 1998; Cohen \& Shurin, 2003; Antón-Pardo \& Armengol, 2010; Frisch et al., 2012; Antón-Pardo et al., 2013) as well as vegetation and invertebrates (Brouwer \& Roelofs, 2001; Jenkins \& Boulton, 2007; Ortells et al., 2012; Antón-Pardo et al., 2013) after pond restoration. In any case, due to our sample design, it is impossible to effectively distinguish between the dispersal and egg bank contributions to the zooplankton communities of the new lagoons. Nevertheless, both mechanisms likely act together to enhance community recovery after lagoon restoration.

We found differences between the new and old lagoons in their physical and chemical water compositions but not in their zooplankton compositions. However, some environmental variables, such as water level, conductivity and nutrient concentrations (especially organic nutrients), were related in the NMDS analysis of the zooplankton samples. This would suggest that the differences in the environmental variables are not large enough to cause a substantial modification in zooplankton species composition. Water level and salinity fluctuations are characteristic of aquatic ecosystems in Mediterranean climates (Alvarez-Cobelas et al., 2005; Beklioglu et al., 2007), and salinity has been described as an important driver determining community structure (Boix et al., 2008) and species distribution at a regional scale (Gascón et al., 2016) in Mediterranean wetlands. The strong variability in salinity and nutrient concentration is one of the main constraints that limit the colonization of these habitats to just a few euryhaline species adapted to this variability. Although strict marine or freshwater species may arrive at these lagoons during sea storms or flooding events, they rarely achieve stable populations if they cannot tolerate salinity fluctuations (Quintana et al., 1998b; Brucet et al., 2005). Regarding seasonal variations in species composition, once a zooplankton species tolerates the environmental filtering of salinity variability, its relative abundance follows the flooding - confinement pattern described for these confined coastal lagoons (Quintana et al., 1998b). The zooplankton response to this pattern, however, arises with some degree of delay (Brucet et al., 2005; Badosa et al., 2007), which makes it difficult to establish the relationship between species composition and the physical and chemical variables. A dependence on the water turnover rate with different degrees of delay has also been observed in nutrient and chlorophyll- $a$ concentrations (Quintana et al., 1998a). Thus, environmental variability affects zooplankton species composition at two different scales. First, it limits the species presence to those that can overcome the constriction caused by strong environmental variability. Second, it determines species dominance by means of the flooding - confinement pattern to which zooplankton respond with a certain degree of delay. Since the new and old lagoons in La Pletera saltmarshes do not differ at these two scales, the zooplankton composition does not show significant differences between these types of lagoons.

Regarding top-down control, fish were absent in the new lagoons in the first months before the hydric connection, and the fish density was low in the new lagoons in the first months after connection (unpublished data). Thus, it seems that fish predation pressure has not had a strong effect on the zooplankton composition in these habitats since the composition was similar between the old and new lagoons even before the hydric connection. López-Flores et al. (2006) suggest the larger importance of bottom-up control in aquatic ecosystems strongly affected by environmental constraints. Badosa et al. (2007) found a smaller effect of fish predation on species composition in the same lagoons but a stronger effect on 
zooplankton size distribution. Moreover, fish predation pressure is also subject to seasonal variability (being higher in summer), as are the physical and chemical characteristics of water. Thus, it is likely that the effects of fish predation and water characteristics have certain covariations. Regarding macroinvertebrates, two potential predator species may achieve high densities in these lagoons: the amphipod Gammarus aequicauda and the Heteroptera Sigara stagnalis. The former appears in high densities during spring and summer, especially in the new lagoons, while the latter only peak occasionally in space and time (unpublished data). Although the main diet is not based on zooplankton in either species (Savage, 1989; Tachet et al., 2000; Monakov, 2003), both taxa may predate zooplankton (Murillo \& Recasens, 1986; MacNeil et al., 1997; Kelly et al., 2002; Compte et al., 2012). Thus, a certain top-down control caused by invertebrate predation should not be discarded.

Restoration is important in terms of community succession and colonization processes, and substantial enhancement in species richness and the appearance of many new species after restoration have been reported (Antón-Pardo \& Armengol, 2010; Antón-Pardo et al., 2013). Our results show that zooplankton may be useful as a proxy for short-term restoration success due to their fast response and high dispersal ability. Of course, it does not necessarily mean that the whole ecosystem achieves maturity so quickly. Plants often colonize restored habitats more slowly, thus conditioning the recovery of the structural and functional attributes of aquatic ecosystems (Williams et al., 2008; Ruhí et al., 2016). Benthic macroinvertebrate colonization and succession dynamics after restoration have been described as fast and usually related to dispersal abilities (Ruhí et al., 2009; Miguel-Chinchilla et al., 2014), but they are affected by differences in habitat structure, such as those provided by plants (Cañedo-Argüelles et al., 2011; Kim et al., 2014). Thus, although wetlands are ecosystems with high turnover rates, the recovery of all of the functional and structural attributes after a restoration might require a long period of time (Moreno-Mateos et al., 2012 and 2015). In summary, restoration effectiveness in coastal lagoons cannot be assessed without the use of several structural and functional indicators that usually respond in the long term. However, rapid response indicators such as zooplankton can provide a quick idea of whether the restoration criteria applied are adequate. In the case of La Pletera, the zooplankton indicator suggests that the restoration criteria used, based on the recovery of ecological functioning and the conservation of its characteristic hydrological dynamics (Quintana et al., 2018), are appropriate.

\section{ACKNOWLEDGEMENTS}

We would like to thank Rosa Miracle for her teaching on several topics covered in this paper, from the study of coastal lagoons affected by human impacts to the tolerance of rotifer species, such as Brachionus plicatilis, to oxygen depletion to zooplankton species composition and dynamics and their relationship with environmental factors.

This work was supported by a grant from the Ecuadorian scholarship program SENESCYT (Globo Común), the Life+ Program of the European Commission (Life Pletera; LIFE13NAT/ES/ 001001), the Spanish Ministerio de Economía y Competitividad (CGL2016-76024-R), the Generalitat de Catalunya (2014 SGR 484) and by a PhD grant from the Ministerio de Educación, Cultura i Deporte (FPU014/06783) held by D C-M.

\section{REFERENCES}

ALEKSEEV, V. R., \& Y. I. STAROBOGATOV. 1996. Types of diapause in Crustacea: definitions, distribution, evolution. Hydrobiologia, 320(1-3): 15-26. DOI: 10.1007/BF00016801

ANTHONY, A., J. ATWOOD, P. AUGUST, C. BYRON, S. COBB, C. FOSTER, C. FRY, A. GOLD, K. HAGOS, L. HEFFNER, D. O. KELLOGG， K. LELLIS-DIBLE, J. J. OPALUCH, C. OVIATT, A. PFEIFFERHERBERT, N. ROHR, L. SMITH, T. SMYTHE, J. SWITF \& N. VINHATEIRO. 2009. Coastal Lagoons and Climate Change: Ecological and Social Ramifications in U . S . Atlantic and Gulf Coast Ecosystems. Ecology and Society, 14(1): 8. DOI: 10.1890/0012- 
9658(2007)88[2947:ETACHH]2.0.CO;2

ANTÓN-PARDO, M. \& X. ARMENGOL. 2010.

Zooplankton community from restored peridunal ponds in the Mediterranean region ( L'Albufera Natural Park, Valencia, Spain ). Limnetica, 29(1): 133-144. DOI: 10.23818/ limn.29.10

ANTÓN-PARDO, M., X. ARMENGOL \& R. ORTELLS. 2016. Zooplankton biodiversity and community structure vary along spatiotemporal environmental gradients in restored peridunal ponds. Journal of Limnology, 75(1): 193-203. DOI: 10.4081/jlimnol.2015.1305

ANTÓN-PARDO, M., C. OLMO, J. M. SORIA \& X. ARMENGOL. 2013. Effect of restoration on zooplankton community in a permanent interdunal pond. Annales De Limnologie-International Journal of Limnology, 49(2): 97-106. DOI: $10.1051 / \mathrm{limn} / 2013042$

APHA., AWWA \& WEF. 1992. Standard Methods for the Examination of Water and Wastewater. Standard Methods, 541. ISBN 9780875532356

AUDET, C., S. MACPHEE \& W. KELLER. 2013. Colonization of constructed ponds by crustacean zooplankton: local and regional influences. Journal of Limnology, 72(3): 43. DOI: $10.4081 / \mathrm{jlimnol} .2013 . \mathrm{e} 43$

BADOSA, A., D. BOIX, S. BRUCET, R. LÓPEZ-FLORES, S. GASCÓN \& X. D. QUINTANA. 2007. Zooplankton taxonomic and size diversity in Mediterranean coastal lagoons (NE Iberian Peninsula): Influence of hydrology, nutrient composition, food resource availability and predation. Estuarine, Coastal and Shelf Science, 71(1-2): 335-346. DOI: 10.1016/j.ecss.2006.08.005

BADOSA, A., D. BOIX, S. BRUCET, R. LÓPEZ-FLORES \& X. D. QUINTANA. 2006. Nutrients and zooplankton composition and dynamics in relation to the hydrological pattern in a confined Mediterranean salt marsh (NE Iberian Peninsula). Estuarine, Coastal and Shelf Science, 66(3-4): 513-522. DOI: $10.1016 /$ j.ecss.2005.10.006

BADOSA, A., D. BOIX, S. BRUCET, R. LÓPEZ-FLORES \& X. D. QUINTANA. 2007. Short-term effects of changes in water management on the limnological characteris- tics and zooplankton of a eutrophic Mediterranean coastal lagoon (NE Iberian Peninsula). Marine Pollution Bulletin, 54(8): 1273-1284. DOI: 10.1016/j.marpolbul.2007.01.021

BADOSA, A., D. FRISCH, A. ARECHEDERRA, L. SERRANO \& A. J. GREEN. 2010. Recovery of zooplankton diversity in a restored Mediterranean temporary marsh in Doñana National Park (SW Spain). Hydrobiologia, 654(1): 67-82. DOI: 10.1007/s10750-010-0370-0

BEKLIOGLU, M., S. ROMO, I. KAGALOU, X. QUINTANA \& E. BÉCARES. 2007. State of the art in the functioning of shallow Mediterranean lakes: Workshop conclusions. Hydrobiologia, 584 (1): 317-326. DOI: 10.1007/ s10750-007-0577-x

BILTON, D. T., J. R. FREELAND \& B. OKAMURA. 2001. Dispersal in freshwater invertebrates. Annual Review of Ecology and Systematics, 32(1): 159. DOI: 10.1146/annurev. ecolsys.32.081501.114016

BOHONAK, A. J. \& H. H. WHITEMAN. 1999. Dispersal of the fairy shrimp Branchinecta coloradensis (Anostraca): Effects of hydroperiod and salamanders. Limnology and Oceanography, 44(3): 487-493. DOI: 10.4319/1o. 1999.44.3.0487

BOIX, D., S. GASCÓN, J. SALA, A. BADOSA, S. BRUCET, R. LÓPEZ-FLORES, M. MARTINOY, J. GRIFE \& X. D. QUINTANA. 2008. Patterns of composition and species richness of crustaceans and aquatic insects along environmental gradients in Mediterranean water bodies. Hydrobiologia, 597(1): 53-69. DOI: 10.1007/s10750-007-9221-z

BORCARD, D., P. LEGENDRE \& P. DRAPEAU. 1992. Partialling out the Spatial Component of Ecological Variation. Ecology, 73(3): 1045-1055. DOI: 10.2307/1940179

BRENDONCK, L. \& L. DE MEESTER. 2003. Egg banks in freshwater zooplankton: Evolutionary and ecological archives in the sediment. Hydrobiologia, 491: 65-84. DOI: 10.1023/A:1024454905119

BROUWER, E. \& J. G. M. ROELOFS. 2001. Degraded softwater lakes: Possibilities for restoration. Restoration Ecology, 9(2): 155-166. DOI: 10.1046/j.1526-100X.2001. 009002155.x 
BRUCET, S., D. BOIX, R. LÓPEZ-FLORES, A. BADOSA, R. MORENO-AMICH \& X. D. QUINTANA. 2005. Zooplankton structure and dynamics in permanent and temporary Mediterranean salt marshes: taxon-based and size-based approaches. Archiv Für Hydrobiologie, 162(April): 535-555. DOI: 10.1127/ 0003-9136/2005/0162-0535

CAÑEDO-ARGÜELLES, M. \& M. RIERADEVALL. 2011. Early succession of the macroinvertebrate community in a shallow lake: response to changes in the habitat condition. Limnologica-Ecology and Management of Inland Waters, 41(4): 363-370. DOI: 10.1016/j.limno.2011.04.001

CARRILLO, P., L. CRUZ-PIZARRO, R. MORALES \& P. SÁNCHEZ-CASTILLO. 1987. Cambios estacionales en las comunidades de fitoplancton y de zooplancton de la Albufera de Adra. Limnetica, 3: 243-254.

CCE. 1992. Directiva 92/43/CEE del Consejo relativa a la conservación de los hábitats naturales y de la fauna y flora silvestres. Diario Oficial de Las Comunidades Europeas.

COBELAS, M. A., C. ROJO \& D. G. ANGELER. 2005. Mediterranean limnology: current status, gaps and the future. Water, 64(1): 13-29. DOI: $10.4081 /$ jlimnol.2005.13

COGNETTI, G. \& F. MALTAGLIATI. 2000. Biodiversity and adaptive mechanisms in brackish water fauna. Marine Pollution Bulletin, 40(1): 7-14. DOI: 10.1016/S0025-326X (99)00173-3

COHEN, G. M. \& J. B. SHURIN. 2003. Scale-dependence and mechanisms of dispersal in freshwater zooplankton. Oikos, 103(3): 603-617. DOI: 10.1034/j.1600-0706.2003. 12660.x

COMÍN, F., M. MENÉNDEZ \& E. FORÉS. 1987. Salinidad y nutrientes en las lagunas costeras del Delta del Ebro. Limnética, 3: 1-8. COMMISSION, D. E. E. 2017. LIFE and Coastal Habitats. DOI: 10.2779/443494

COMPTE, J., S. GASCÓN, X. D. QUINTANA $\&$ D. BOIX. 2012. The effects of small fish presence on a species-poor community dominated by omnivores: Example of a size-based trophic cascade. Journal of Experimental Marine Biology and Ecology, 418: 1-11. DOI: 10.1016/j.jembe.2012.03.004

COTTENIE, K., E. MICHELS, N. NUYTTEN \& L. DE MEESTER. 2003. Zooplankton Metacommunity Structure: Regional Vs. Local Processes in Highly Interconnected Ponds. Ecology, 84(4): 991-1000. DOI: 10.1890/00129658(2003)084[0991:ZMSRVL]2.0.CO;2

DE MEESTER, L., A. GÓMEZ, B. OKAMURA \& K. SCHWENK. 2002. The Monopolization Hypothesis and the dispersal-gene flow paradox in aquatic organisms. Acta Oecologica, 23(3): 121-135. DOI: 10.1016/S1146-609X (02)01145-1

DE STASIO, B. T. 1990. The role of dormancy and emergence patterns in the dynamics of a freshwater zooplankton community. Limnology and Oceanography, 35(5): 1079-1090. DOI: $10.4319 / 10.1990 .35 .5 .1079$

DOADRIO, I., S. PEREA, P. GARZÓN-HEYDT \& J. L. GONZÁLEZ. 2011. Ictiofauna Continental Española. Bases para su seguimiento. DG Medio natural y Política Forestal. MARM, Madrid, Spain.

DRAKE, D. C. \& R. J. NAIMAN. 2000. An evaluation of restoration efforts in fishless lakes stocked with exotic trout. Conservation Biology, 14(6): 1807-1820. DOI: 10.1046/j. 1523-1739.2000.99032.x

FRISCH, D., K. COTTENIE, A. BADOSA \& A. J. GREEN. 2012. Strong spatial influence on colonization rates in a pioneer zooplankton metacommunity. PLoS ONE, 7(7): 1-10. DOI: 10.1371/journal.pone.0040205

FRISCH, D., H. RODRÍGUEZ-PÉREZ \& A. J. GREEN. 2006. Invasion of artificial ponds in Doñana Natural Park, southwest Spain, by an exotic estuarine copepod. Aquatic Conservation: Marine and Freshwater Ecosystems, 16(5): 483-492. DOI: 10.1002/aqc.718

GASCÓN, S., I. ARRANZ, M. CAÑEDO-ARGÜELLES, A. NEBRA, A. RUHÍ, M. RIERADEVALL, N. CAIOLA, J. SALA, C. IBÀÑEZ, X. D. QUINTANA \& D. BOIX. 2016. Environmental filtering determines metacommunity structure in wetland microcrustaceans. Oecologia, 181(1): 193-205. DOI: $10.1007 / \mathrm{s} 00442-015-3540-\mathrm{y}$

HAIRSTON, N. G. \& C. E. CÁCERES. 1996. Distribution of crustacean diapause: micro- and 
macroevolutionary pattern and process. Hydrobiologia, 320(1-3): 27-44. DOI: 10.1007/ BF00016802

HOBBS, R. J. \& J. A. HARRIS. 2001. Restoration Ecology: Repairing the Earth's Ecosystems in the New Millennium. Restoration Ecology, 9(2): 239-246. DOI: 10.1046/j.1526100x.2001.009002239.x

INCAGNONE, G., F. MARRONE, R. BARONE, L. ROBBA \& L. NASELLIFLORES. 2015. How do freshwater organisms cross the "dry ocean"? A review on passive dispersal and colonization processes with a special focus on temporary ponds. Hydrobiologia, 750(1): 103-123. DOI: 10.1007/s10750014-2110-3

JENKINS, D. G. \& A. L. BUIKEMA. 1998. Do similar communities develop in similar sites? A test with zooplankton structure and function. Ecological Monographs, 68(3): 421-443. DOI: 10.1890/0012-9615(1998)068 [0421:DSCDIS]2.0.CO;2

JENKINS, K. M. \& A. J. BOULTON. 2007. Detecting impacts and setting restoration targets in arid-zone rivers: Aquatic micro-invertebrate responses to reduced floodplain inundation. Journal of Applied Ecology, 44(4): 823-832. DOI: 10.1111/j.1365-2664. 2007.01298.x

KELLER, W. \& N. D. YAN. 1998. Biological recovery from lake acidification: Zooplankton communities as a model of patterns and processes. Restoration Ecology, 6(4): 364-375. DOI: 10.1046/j.1526-100X.1998. 06407.X

KELLY, D. W., J. T. A. DICK \& W. I. MONTGOMERY. 2002. The functional role of Gammarus (Crustacea, Amphipoda): shredders,predators, or both? Hydrobiologia, 485: 199-203. DOI: 10.1023/A:1021370405349

KIM, D. G., H. J. KANG, M. J. BAEK, C. Y. LEE, J. G. KIM \& Y. J. BAE. 2014. Analyses of benthic macroinvertebrate colonization during the early successional phases of created wetlands in temperate Asia. Fundamental and Applied Limnology/Archiv für Hydrobiologie, 184(1): 35-49. DOI: 10.1127/18639135/2014/0502

KJERFVE, B. 1994. Coastal Lagoons. In: Coast- al Lagoon Processes. B. Kjerfve (ed.):1-8. Elsevier. DOI: 10.1201/EBK1420088304-c1

LEGENDRE, P. \& E. D. GALLAGHER. 2001. Ecologically meaningful transformations for ordination of species data. Oecologia, 129(2): 271-280. DOI: 10.1007/s004420100716

LEGENDRE, P. \& L. LEGENDRE. 1998. Numerical Ecology. Elsevier Science B.V. Québec. Canada. DOI: 10.1017/CBO9781107415324. 004

LILLEBØ, A. I., P. STÅLNACKE \& G. D. GOOCH. 2015. Coastal lagoons in europe. IWA Publishing: 107-131, London, UK.

LÓPEZ-FLORES, R., D. BOIX, A. BADOSA, S. BRUCET \& X. D. QUINTANA. 2006. Pigment composition and size distribution of phytoplankton in a confined Mediterranean salt marsh ecosystem. Marine Biology, 149(6): 1313-1324. DOI: 10.1007/s00227-006-0273-9 LOUETTE, G. \& L. DE MEESTER. 2005. High Dispersal Capacity of Cladoceran Zooplankton in Newly Founded Communities. Ecology, 86(2): 353-359. DOI: 10.1890/04-0403

MACNEIL, C., J. T. A. DICK \& R. W. ELWOOD. 1997. the Trophic Ecology of Freshwater Gammarus Spp. (Crustacea:Amphipoda): Problems and Perspectives Concerning the Functional Feeding Group Concept. Biological Reviews, 72(3): 349-364. DOI: 10.1111/j.1469-185X.1997.tb00017.x

MALLEY, D. F., S. G. LAWRENCE, M. A. MACIVER, W. J. FINDLAY. 1989. Range of variation in estimates of dry weight for planktonic crustacea and rotifera from temperate north American lakes. Can. Tech. Rep. Fish. Aquat. Sci. 1666: 49. DOI: 10.1139/f04-178

MARRONE, F., S. LO BRUTTO, A. K. HUNDSDOERFER \& M. ARCULEO. 2013. Overlooked cryptic endemism in copepods: Systematics and natural history of the calanoid subgenus Occidodiaptomus Borutzky 1991 (Copepoda, Calanoida, Diaptomidae). Molecular Phylogenetics and Evolution, 66(1): 190-202. DOI: 10.1016/j.ympev.2012.09.016 MENCIÓ, A., X. CASAMITJANA, J. MAS-PLA, N. COLL, J. COMPTE, M. MARTINOY, J. PASCUAL \& X. D. QUINTANA. 2017. Groundwater dependence of coastal lagoons: The case of La Pletera salt marshes 
(NE Catalonia). Journal of Hydrology, 552: 793-806. DOI: 10.1016/j.jhydrol.2017.07.034 MIGUEL-CHINCHILLA, L., D. BOIX, S. GASCÓN \& F. COMÍN. 2014. Taxonomic and functional successional patterns in macroinvertebrates related to flying dispersal abilities: a case study from isolated manmade ponds at reclaimed opencast coal mines. Hydrobiologia, 732(1): 111-122. DOI: 10.1007/s10750-014-1851-3

MIRACLE, M. R., M. SERRA, E. VICENTE \& C. BLANCO. 1987. Distribution of Brachionus species in Spanish mediterranean wetlands. Hydrobiologia, 147(1): 75-81. DOI: $10.1007 / \mathrm{BF} 00025728$

MIRACLE, M. R., M. P. GARCÍA \& E. VICENTE. 1984. Heterogeneidad Espacial De Las Comunidades Fitoplanctonicas De La Albufera De Valencia. Limnetica, 1: 20-31.

MONAKOV, A. B. 2003. Feeding of freshwater invertebrates. Kenobi Productions, Ghent. 373 pp.

MOREIRA, G. S., J. B. JILLETT, W. B. VERNBERG \& M. WEINRICH. 1982. The combined effects of temperature and salinity on the survival of Euterpina acutifrons (Dana) (Copepoda, Harpacticoida) from the New Zealand and Brazilian coasts. Journal of Plankton Research, 4(1): 85-91. DOI: 10.1093/ plankt/4.1.85

MORENO-MATEOS, D., P. MELI, M. I. VARA-RODRÍGUEZ \& J. ARONSON. 2015. Ecosystem response to interventions: Lessons from restored and created wetland ecosystems. Journal of Applied Ecology, 52(6): 1528-1537. DOI: $10.1111 / 1365-2664.12518$

MORENO-MATEOS, D., M. E. POWER, F. A. COMÍN \& R. YOCKTENG. 2012. Structural and functional loss in restored wetland ecosystems. PLoS Biology, 10(1). DOI: 10.1371/journal.pbio.1001247

MURCIA, C., J. ARONSON, G. H. KATTAN, D. MORENO-MATEOS, K. DIXON \& D. SIMBERLOFF. 2014. A critique of the "novel ecosystem" concept. Trends in Ecology and Evolution, 29(10): 548-553. DOI: 10.1016/j.tree.2014.07.006

MURILLO, J. \& L. RECASENS. 1986. Habitos Alimentarios de Sigara Lateralis (Heteroptera,
Corixidae). Miscellania Zoologica, 10: 135-140.

NEUMANN, B., A. T. VAFEIDIS, J. ZIMMERMANN \& R. J. NICHOLLS. 2015. Future coastal population growth and exposure to sea-level rise and coastal flooding - A global assessment. PLoS ONE, 10(3). DOI: 10.1371/journal.pone.0118571

NEWTON, A., A. BRITO, J. ICELY, V. DEROLEZ, I. CLARA, S. ANGUS, G. SCHERNEWSKI, M. INÁCIO, A. LILLEBØ, A. SOUSA, B. BÉJAOUI, C. SOLIDORO, M. TOSIC, M. CAÑEDO-ARGÜELLES, M. YAMAMURO, S. REIZOPOULOU, H. TSENG, D. CANU, L. ROSELLI, M. MAANAN, S. CRISTINA, A. RUIZ-FERNÁNDEZ, R. DE LIMA, B. KJERFVE, N. RUBIO-CISNEROS, A. PÉREZ-RUZAFA, C. MARCOS, R. PASTRES, F. PRANOVI, M. SNOUSSI, J. TURPIE, Y. TUCHKOVENKO, B. DYACK, J. BROOKES, R. POVILANSKAS \& V. KHOKHOV. 2018. Assessing, quantifying and valuing the ecosystem services of coastal lagoons. Journal For Nature Conservation, 44: 50-65. DOI: 10.1016/j.jnc.2018.02.009

OKSANEN, J., R. KINDT, P. LEGENDRE, B. O'HARA, G. L. SIMPSON, P. SOLYMOS, M. H. H. STEVENS \& H. WAGNER. 2009. Vegan: Community Ecology Package. R Foundation for Statistical Computing. R Package Version 1.15-3.

OLMO, C., X. ARMENGOL, M. ANTÓN-PARDO \& R. ORTELLS. 2016. The environmental and zooplankton community changes in restored ponds over 4 years. Journal of Plankton Research, 38(3): 490-501. DOI: 10.1093/plankt/fbw021

OLMO, C., X. ARMENGOL \& R. ORTELLS. 2012. Re-establishment of zooplankton communities in temporary ponds after autumn flooding: Does restoration age matter? Limnologica, 42(4): 310-319. DOI: 10.1016/ j.limno.2012.08.005

O'MALLEY, M. A. 2007. The nineteenth century roots of 'everything is everywhere'. Nature Reviews Microbiology, 5: 647-651. DOI: 10.1038/nrmicro1711

ORTELLS, R., C. OLMO \& X. ARMENGOL. 
2012. Colonization in action: Genetic characteristics of Daphnia magna Strauss (Crustacea, Anomopoda) in two recently restored ponds. Hydrobiologia, 689(1): 37-49. DOI: 10.1007/s10750-011-0741-1

PASCUAL, J. \& M. MARTINOY. 2017. Seguimiento De Niveles De Agua Y Salinidad Del Proyecto Life Pletera. Ajuntament de Torroella de Montgrí: 21-38

PÉREZ-RUZAFA, A. \& C. MARCOS. 2005. Pressures on Mediterranean coastal lagoons as a consequence of human activities. In: Fletcher, C., Spencer, T., Da Mosto, J. \& Campostrini, P. (Eds.), Flooding and Environmental Challenges for Venice and its Lagoon: State of Knowledge. Cambridge University Press, Cambridge: 545-555.

PUTT, M. \& D. K. STOECKER. 1989. An experimentally determined carbon: volume ratio for marine "oligotrichous" ciliates from estuarine and coastal waters. Limnology and Oceanography, 34(6): 1097-1103. DOI: 10.4319/1o.1989.34.6.1097

QUINTANA, X. D., D. BOIX, X. CASAMITJANA, À. COLOMER, J. COMPTE, D. CUNILLERA-MONTCUSÍ, S. GASCÓN, F. GICH, A. MENCIÓ, M. MARTINOY, J. MONTANER, J. PASCUAL, J. SALA, J. SOLÀ \& I. TORNERO. 2018. Management and Restoration Actions of Confined Mediterranean Coastal Lagoons in the Empordà and Baix Ter wetlands. In: Quintana, X.D., Boix, D., Gascón, S. and Sala, J. Eds. Management and restoration of Mediterranean coastal lagoons in Europe. Recerca i Territori, 10.

QUINTANA, X. D., R. MORENO-AMICH \& F. A. COMÍN. 1998a. Nutrient and plankton dynamics in a Mediterranean salt marsh dominated by incidents of flooding. Part 1: Differential confinement of nutrients. Journal of Plankton Research, 20(11): 2089-2107. DOI: 10.1093/plankt/20.11.2089

QUINTANA, X. D., F. A. COMIN \& R. MORENO-AMICH, 1998b. Nutrient and plankton dynamics in a Mediterranean salt marsh dominated by incidents of flooding. Part 2: Response of the zooplankton community to disturbances. Journal of Plankton Research, 20(11): 2109-2127. DOI: 10.1093/plankt/20.
11.2109

QUINTANA, X., C. FEO, A. CROUS, J. GESTI, J. FONT \& Q. POU-ROVIRA. 2009. Actuacions i reptes en la conservació dels aiguamolls del Baix Ter. Papers Del Montgrí, 30., 94.

R DEVELOPMENT CORE TEAM. 2008. R: A language and environment for statistical computing R Foundation for Statistical Computing, Vienna.

RAMDANI, M., N. ELKHIATI, R. J. FLOWER, H. H. BIRKS, M. M. KRAÏEM, A. A. FATHI \& S. T. PATRICK. 2001. Open water zooplankton communities in North African wetland lakes: the Cassarino Project. Aquatic Ecology, 35: 319-333.

ROMO, S., M. J. VILLENA, M. SAHUQUILLO, J. M. SORIA, M. GIMÉNEZ, T. ALFONSO, E. VICENTE \& M. R. MIRACLE. 2005. Response of a shallow Mediterranean lake to nutrient diversion: Does it follow similar patterns as in northern shallow lakes? Freshwater Biology, 50(10): 1706-1717. DOI: 10.1111/j.1365-2427.2005.01432.x

RUHÍ. A., D. BOIX, J. SALA, S. GASCÓN \& X. D. QUINTANA. 2009. Spatial and temporal patterns of pioneer macrofauna in recently created ponds: taxonomic and functional approaches. In: Pond Conservation in Europe: 293-307. Springer, Dordrecht.

RUHÍ, A., G. W. FAIRCHILD, D. J. SPIELES, G. BECERRA-JURADO \& D. MORENO-MATEOS. 2016. Invertebrates in created and restored wetlands. In: Invertebrates in Freshwater Wetlands: 525-564. Springer, Cham.

RUTTNER-KOLISKO, A. 1977. Suggestions for biomass calculation of plankton rotifers. Archiv für Hydrobiologie-BeiheftErgebnisse der Limnologie, 8(7): 1-76.

SAVAGE, A. A. 1989. Adults of the British aquatic Hemiptera Heteroptera. A: Scientific Publication, 50. Freshwater Biological Association, Ambleside. 173 pp.

SCHEFFER, M., S. HOSPER, M. MEIJER, B. MOSS \& E. JEPPESEN. 1993. Alternative equilibria in shalow lakes. Trends in Ecology and Evolution, 8(8): 275-279. DOI: 10.1016/ 0169-5347(93)90254-M

SMALL, C. \& R. J. NICHOLLS. 2003. A global analysis of human settlement in coastal zones. 
Journal of Coastal Research, 19(3): 584-599. DOI: $10.2307 / 4299200$

TACHET, H., P. RICHOUX, M. BOURNAUD \& P. USSEGLIO-POLATERA. 2000. Invertébrés d'eau douce: systématique, biologie, écologie. CNRS editions, Paris. 587 pp.

VALLEJO, S. M. A. 1982. Development and management of coastal lagoons. Oceanologica Acta, Special Issue (1982):397-401. DOI: 10.1016/j.ecss.2012.07.008

VANSCHOENWINKEL, B., S. GIELEN, M. SEAMAN \& L. BRENDONCK. 2009. Wind mediated dispersal of freshwater invertebrates in a rock pool metacommunity: Differences in dispersal capacities and modes. Hydrobiologia, 635(1): 363-372. DOI: 10.1007/s10750-0099929-z

VICENTE, E. \& M. R. MIRACLE. 1992. The coastal lagoon Albufera de Valencia: an ecosystem under stress. Limnetica, 8: 87-100.
VOLLENWEIDER, R. A., F. GIOVANARDI, G. MONTANARI \& A. RINALDI. 1998. Characterization of the trophic conditions of marine coastal waters with special reference to the Adriatic Sea: Proposal for a trophic scale, turbididty and generealized water quality. Envirometrics, 9(June 1997): 329-357. DOI: 10.1002/(SICI)1099-095X(199805/06) 9:33.3.CO;2-0

WEST, E. J., K. A. PITT, D. T. WELSH, K. KOOP \& D. RISSIK. 2009. Top-down and bottom-up influences of jellyfish on primary productivity and planktonic assemblages. Limnology and Oceanography, 54(6): 2058-2071. DOI: 10.4319/lo.2009.54.6.2058

WILLIAMS, P., M. WHITFIELD \& J. BIGGS. 2008. How can we make new ponds biodiverse? A case study monitored over 7 years. Hydrobiologia, 597(1): 137-148. DOI: 10. 1007/s10750-007-9224-9.

Con el apoyo de:
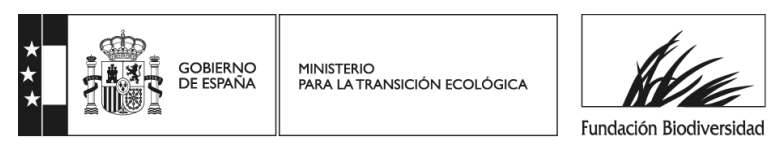